\title{
OUTPUT OF SPERMATOZOA AND FLUID BY THE TESTIS OF THE RAM AND ITS RESPONSE TO OXYTOCIN
}

\author{
J. K. VOGLMAYR \\ Worcester Foundation for Experimental Biology, Shrewsbury, \\ Massachusetts 01545, U.S.A.
}

(Received 12th Fuly 1974)

The space between the internal and external lamellae of the boundary tissue surrounding individual seminiferous tubules is occupied by a layer of spindleshaped cells that are particularly well developed in the ram and bear some resemblance to smooth muscle fibres (see Setchell, Scott, Voglmayr \& Waites, 1969, for references). The seminiferous tubules are, therefore, capable of rhythmic contractions and these movements may facilitate the release of spermatozoa from the seminiferous epithelium and transport of spermatozoa out of the testis (see Setchell et al., 1969). Since oxytocin has been found to increase the frequency of contractions of seminiferous tubules in vitro (Niemi \& Kormano, 1965), it might also be expected to influence the sperm output by the testis in vivo.

Four Merino rams, aged 2 to 5 years and weighing between 46 and $60 \mathrm{~kg}$, were kept in a controlled environment (Voglmayr, Scott, Setchell \& Waites, 1967). A silicon rubber catheter was placed into one rete testis of each animal (Voglmayr et al., 1967) and a catheter (PVC, $0.87 \mathrm{~mm}$ i.d., $1.27 \mathrm{~mm}$ o.d.: Dural Plastics, Dural, N.W.W.; or Teflon, $1.26 \mathrm{~mm}$ i.d., $1.7 \mathrm{~mm}$ o.d.: Vicra Sterile, Inc., Dallas) was inserted into the recurrent tarsal vein or into the jugular vein. In one animal, a polyethylene catheter $(0.46 \mathrm{~mm}$ i.d., $0.79 \mathrm{~mm}$ o.d.: Becton-Dickinson, Rutherford, N.J.) with a high gloss inner surface was also placed into the ductus deferens for collection of cauda epididymal semen (Sexton, Amann \& Flipse, 1971; Voglmayr \& Amann, 1973). In order to reduce the possible factor of a diurnal variation in the secretory activity of the testis, each experiment was performed at different times of the day between 09.00 and 18.00 hours. The testicular secretion was collected into $2-\mathrm{ml}$ polyethylene receptables which were exchanged at 20-min intervals. The volume of the rete testis fluid was measured in a $0 \cdot 01-\mathrm{ml}$ graduated pipette and the concentration of spermatozoa in the fluid was calculated from duplicate counts in a haemocytometer. Normal saline $(0.9 \%)$ was infused into the tarsal or jugular vein at a rate of $10 \mathrm{ml} / \mathrm{hr}$ throughout the experiment. After control collections had been made, plasma oxytocin levels were elevated by a combination of a priming injection (12 mU/kg: Syntocinon, Santoz, Basel, or Pitocin, Sigma) and continuous infusion $(1.5 \mathrm{mU} / \mathrm{kg} / \mathrm{min})$ for $1 \mathrm{hr}$. The dosage of oxytocin was calculated from an assumed half-life of $4 \mathrm{~min}$, the volume of blood $/ \mathrm{kg}$ body weight, and the concentration of oxytocin that increased the frequency of contractions 
of rat seminiferous tubules in vitro (Niemi \& Kormano, 1965). Thus, for a ram weighing $50 \mathrm{~kg}$, this dosage would amount to $75 \mathrm{mU} / \mathrm{min}$, which was in the range reported for rams after stimulation of the seminal vesicles and ampullae (Debackere, Peeters \& Tuyttens, 1961). At this dosage, epididymal semen was discharged from the catheterized ductus deferens in distinct waves of 30- to 40 -sec duration recurring at intervals of 1 to $3 \mathrm{~min}$, and less than half the time
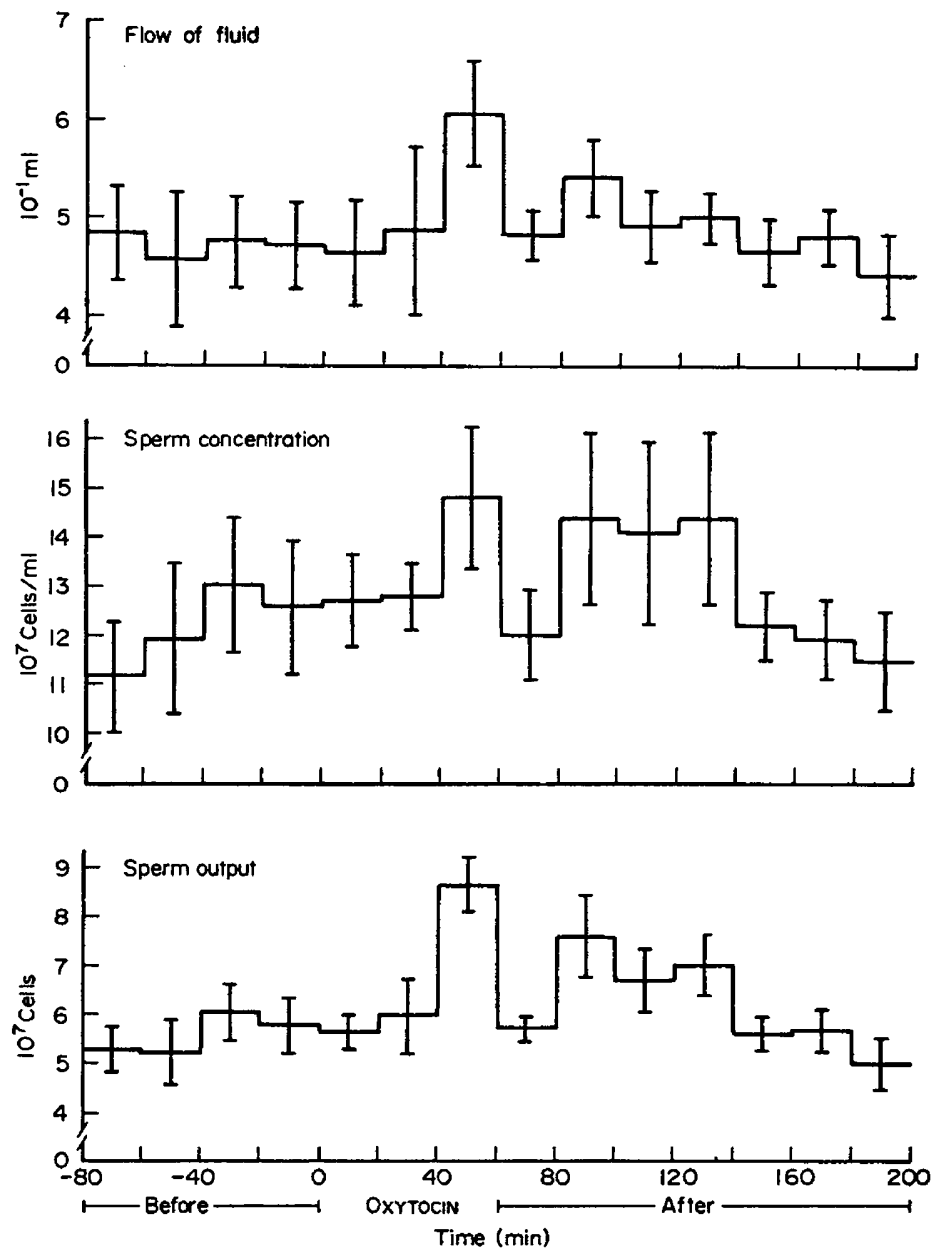

TEXT-FIG. 1. Output of spermatozoa and fluid by the ram testis and concentration of spermatozoa in the fluid before, during and after infusion of oxytocin $(1.5 \mathrm{mU} / \mathrm{kg} / \mathrm{min}$ following a priming injection of $12 \mathrm{mU} / \mathrm{kg}$ ). Vertical lines represent the S.E.M. Values are the means of six replicates from four rams.

was required to collect the same amount of epididymal semen obtained without oxytocin. By contrast, a priming injection of $18 \mathrm{mU} / \mathrm{kg}$ of oxytocin and an infusion rate of $3.5 \mathrm{mU} / \mathrm{kg} / \mathrm{min}$, which was used in a preliminary study, reduced the output of fluid and spermatozoa by the catheterized testis by about $75 \%$ between 80 and $100 \mathrm{~min}$ after injection of the priming dose; this may have been due to tonic contraction of the seminiferous tubules (Niemi \& Kormano, 1965). 
The statistical significance between the data for control collections and collections made during and after oxytocin infusion was assessed by $t$ tests using the interaction mean squares from the analysis of variance to determine the standard errors and associated degrees of freedom.

Despite some fluctuations between control collections, it is apparent that the response of the testis to elevated oxytocin levels was biphasic, as judged by the output of spermatozoa during and after infusion of the neurohypophysial hormone (Text-fig. 1). The first peak in sperm output was observed between 40 and 60 min after injection of the priming dose and it resulted from an increase in both flow of fluid and concentration of spermatozoa in the fluid. The second increase in sperm output by the testis occurred at about 80 min after the first administration of oxytocin, persisted for approximately $1 \mathrm{hr}$, and was the consequence of higher sperm concentrations in the fluid rather than an increase in the flow of fluid.

The abrupt but brief increase in the flow of fluid and output of spermatozoa during the last 20 min of oxytocin infusion may have been caused by contractions of the smooth muscle cells in the tunica albuginea of the testicular capsule (Cross, 1955) as, for instance, during electroejaculation. In another ram, electrical stimulation briefly increased the flow of rete testis fluid (mean \pm S.D.) from $0.17 \pm 0.033 \mathrm{ml} / 10 \mathrm{~min}$ to $0.24 \pm 0.065 \mathrm{ml} / 10 \mathrm{~min}$, but thereafter it fell to $0.07 \pm 0.023 \mathrm{ml} / 10 \mathrm{~min}$ (J. K. Voglmayr, unpublished observations). The second oxytocin-induced peak in sperm output by the testis was probably the result of increased contractility of the seminiferous tubules, which presumably liberated more spermatozoa from the seminiferous epithelium than during the control period. From the interval between the injection of the priming dose and the second peak in sperm output, it would appear that transport of spermatozoa from their site of formation in the seminiferous tubule to the rete testis requires between 80 and $140 \mathrm{~min}$, depending on the exact location of the cells along the length of the tubule.

The physiological significance of the increased contractility of seminiferous tubules in response to elevated plasma oxytocin levels is not entirely clear. The release of oxytocin upon sexual stimulation (Sharma \& Hays, 1968) apparently influences the muscular contractions of the epididymal duct (Cross, 1955). It thus increases the number of spermatozoa which appear in the ejaculate (Ewy, Bielaniski \& Zapletal, 1963) but the relatively small peaks in sperm output by the testis in response to oxytocin would have little influence on the number of spermatozoa ejaculated. It is conceivable, however, that oxytocin-induced contractions of the seminiferous tubules and of the testicular capsule might serve as a secondary stimulus for a neurogenic mechanism. The reflex release of an oxytocic hormone by massage of the seminal vesicles and ampullae has been well documented (Debackere et al., 1961) and although the precise origin and pathways of the intrinsic nerves of the testis are still undecided in both the efferent and afferent systems (Hodson, 1970), they may be involved in stimulating the hypothalamo-hypophysial complex in response to increased contractility of the seminiferous tubules and the testicular capsule. Such a mechanism could explain the increase of up to $62 \%$ in the daily sperm output from the catheterized testis of another ram during exposure to oestrous ewes for $24 \mathrm{hr}$ 
(J. K. Voglmayr, unpublished observations). In these instances, the increase in sperm output was also due to higher sperm concentrations rather than to an increase in the flow of fluid. It is interesting to note in this context that oxytocin apparently stimulates the Leydig cells, suggesting a trophic action of the nongonadotrophic hormone on the anterior pituitary and increased secretion of interstitial cell-stimulating hormone (Armstrong \& Hansel, 1958).

This study was supported in part by NIH Grant RO1 HD06867 awarded to Dr A. Bartke.

\section{REFERENGES}

Armstrong, D. T. \& Hansel, W. (1958) Effects of hormone treatment on testes development and pituitary function. Int. F. Fert. 3, 296-306.

CRoss, B. A. (1955) The posterior pituitary gland in relation to reproduction and lactation. Br. med. Bull. 11, 151-155.

Debackere, M., Peeters, G. \& Tuyttens, N. (1961) Reflex release of an oxytocic hormone by stimulation of genital organs in male and female sheep studied by a cross-circulation technique. $\mathcal{J}$. Endocr. 22, 321-334.

EwY, Z., BieLAŃsKI, W. \& ZaPLETAL, Z. (1963) Influence of oxytocin on spermatozoa transport in the ductus deferens of the ram. Bull. Akad. pol. Sci., Sér. Sci. biol. 11, 145-148.

Hodson, N. (1970) The nerves of the testis, epididymis, and scrotum. In The Testis, vol. 1, pp. 47-99. Eds. A. D. Johnson, W. R. Gomes and N. L. VanDemark. Academic Press, New York.

Niemi, M. \& Kormano, M. (1965) Contractility of the seminiferous tubule of the postnatal rat testis and its response to oxytocin. Annls Med. exp. Biol. Fenn. 43, 40-42.

Setcheli, B. P., Scott, T. W., Voglmayr, J. K. \& Waites, G. M. H. (1969) Characteristics of testicular spermatozoa and the fluid which transports them into the epididymis. Biol. Reprod. 1, 4066.

Sexton, T. J., Amann, R. P. \& Flipse, R. J. (1971) Free amino acids and protein in rete testis fluid, vas deferens plasma, accessory sex gland fluid, and seminal plasma of the conscious bull. $\mathcal{f}$. Dairy Sci. 54, 412-416.

Sharma, O. P. \& Hays, R. L. (1968) Release of oxytocin due to genital stimulation in bulls. F. Dairy Sci. 51, 966.

VoglmayR, J. K. \& AmanN, R. P. (1973) The distribution of free myo-inositol in fluids, spermatozoa, and tissues of the bull genital tract, and observations on its uptake by the rabbit epididymis. Biol. Reprod. 8, 504-513.

Voglmayr, J. K., Scott, T. W., Setcheld, B. P. \& Waites, G. M. H. (1967) Metabolism of testicular spermatozoa and characteristics of testicular fluid collected from conscious rams. F. Reprod. Fert. 14, 87-99. 